\title{
MARISA ROËSSET, EN LA FRONTERA (1924-1939)*
}

\author{
CONCha Lomba SerRano ${ }^{1}$ \\ Universidad de Zaragoza
}

\begin{abstract}
La misoginia que caracterizó la España del primer tercio del siglo XX y las graves dificultades que las artistas debieron sortear durante esos años definen el contexto en el que se inserta nuestra investigación, cuyo objetivo esencial es analizar la trayectoria artística de Marisa Rosset y Velasco desde que en 1924 se dio a conocer en la Exposición Nacional hasta 1939, fecha en la que concluyó la guerra civil y acabó la etapa esencial de su producción. Durante este período la artista no solo practicó una moderna figuración sino que alcanzó un elevado grado de profesionalización, hechos estos que hicieron de ella una de las pintoras de mayor calidad y más avanzadas de su época y sobre los que este trabajo centra la atención con el propósito de paliar una inmerecida laguna historiográfica.

Palabras clave: Marisa Roësset; Arte contemporáneo; Pintora; Moderna Figuración; Nuevos realismos; Asuntos de género.
\end{abstract}

\section{ON THE FRONTIER: MARISA ROËSSET (1924-1939)}

The misogyny that characterized Spain in the first third of the $20^{\text {th }}$ century and the serious difficulties that artists had to overcome during those years are the two main features that define the context of this paper. Its main objective is to analyze the artistic trajectory of Marisa Roësset and Velasco from 1924 when she made herself known in the National Exhibition through 1939, when the Spanish Civil War ended and the essential phase of her artistic production came to its conclusion. During this period the artist not only practiced a modern figuration but achieved a high degree of professionalization, two facts that made her one of the highest quality and most advanced female painters of her time, and on which this paper focuses attention with the purpose of filling an undeserved historiographical gap.

Key words: Marisa Roësset; Contemporary Art; Female Painter; Modern Figuration; New realism; Gender issues.

Como citar este artículo / Citation: Lomba Serrano, Concha (2018): "Marisa Roësset, en la frontera". En: Archivo Español de Arte, vol.91, núm.362, Madrid, pp. 143-158. https://doi.org/10.3989/aearte 2018.10.

...Si hubiéramos de atender a la expresión física de su arte, diríamos que es una pintura desenvuelta, ágil y vigorosa. Pintura de muchachas modernas que visitan la sierra con frecuencia y lucen sobre el campo de tennis la gracia de su silueta blanca. Pintura sin melindres, que no puede ser de ningún modo lo que fue la pintura del siglo XIX antes de recibir las sacudidas del postimpresionismo...2.

La joven pintora a la que se refiere Antonio Gil Fillol es Marisa Roësset y Velasco que, con apenas veintiún años, concurrió a la Exposición Nacional de 1924 logrando una merecida tercera medalla con un hermoso Autorretrato que no sólo contaba “...con la virtud de revelar, al igual

* El estudio se enmarca en un proyecto más amplio, dedicado a Las Artistas en España entre 1880 y 1939, desarrollado en el seno del grupo de investigación consolidado Vestigium (H20) auspiciado por el Gobierno de Aragón. Un proyecto que, en su fase documental, contó con una Ayuda del "Programa Ibercaja-CAI de Estancias de Investigación".

1 clomba@unizar.es / ORCID iD: http://orcid.org/0000-0003-3098-9844

2 Gil, 1930.

Copyright: (C) 2018 CSIC. Este es un artículo de acceso abierto distribuido bajo los términos de una licencia de uso y distribución Creative Commons Reconocimiento 4.0 Internacional (CC BY 4.0) 


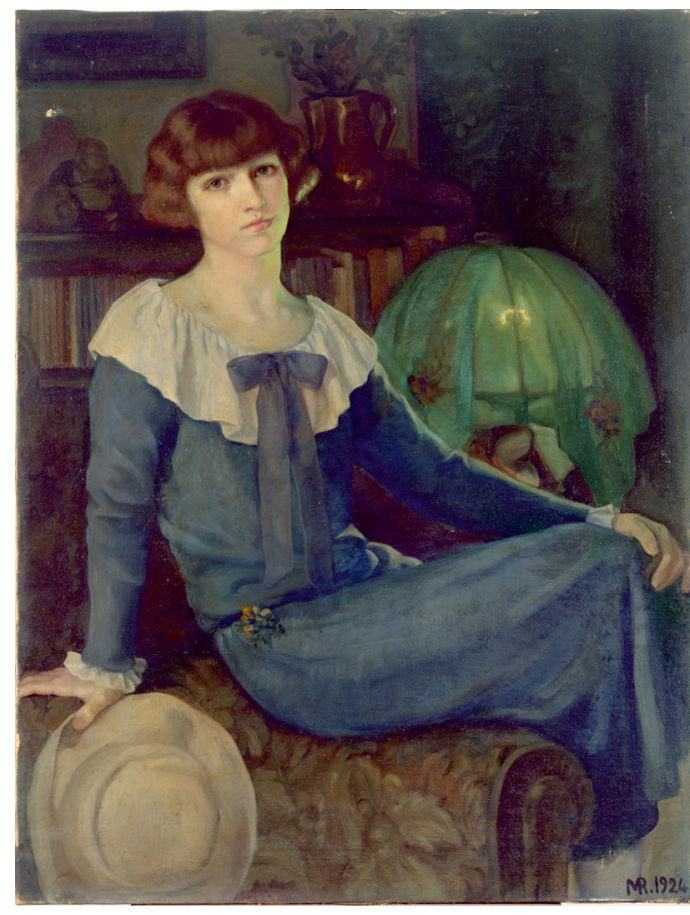

Fig. 1. Autorretrato, 1924, Madrid, MNCARS

que un espejo fiel, la verdad..."3, sino que mostraba la modernidad que la caracterizó, tanto personal como estéticamente, a lo largo de su trayectoria; en especial durante los años que ocupan nuestro estudio, 1924-1939, los principales de su intensa producción artística.

La cuidada puesta en escena del Autorretrato constituye toda una declaración de intenciones, en el doble sentido al que aludía. Representada en el interior de su confortable y elegante domicilio - del que tan sólo se atisban algunos detalles, tamizados por una luz tenue proveniente de una lámpara que ya está encendida-, parece autoafirmarse al contemplar decidida al espectador mostrando la imagen de una mujer moderna: ataviada a la moda - con un vestido tipo charleston y en la mano el preceptivo sombrero que debe lucir toda señorita de buena familia-, y el cabello corto. Tan rotunda y cálida imagen expresa nítidamente tanto su avanzada actitud en el seno de una sociedad que seguía considerando a la mujer como un ángel del hogar y, en consecuencia, reprobaba su trabajo fuera del hogar, como el moderno lenguaje artístico que caracterizó su poética a lo largo de esos años (fig. 1). Una modernidad estilística que, sin embargo, dista de ser la canónica si es que tal término puede emplearse, pues Marisa Roësset se situó en la frontera tanto en el ámbito artístico como en el personal. Y fue ese carácter fronterizo el que no sólo dificultó todavía más su trabajo sino que obstaculizó su fortuna crítica que, dicho sea de paso, ha sido paupérrima ${ }^{4}$. Pues aunque, por desgracia y con notables excepciones, las creadoras europeas y españolas en activo durante el primer tercio del siglo XX no han gozado de los estudios que merecían ${ }^{5}$, la figuración por la que se inclinó y la libertad personal de que hizo gala tampoco ayudaron a su difusión. Paliar esta laguna historiográfica constituye el objetivo de nuestras páginas, organizadas en torno a las dos vertientes que definen su trayectoria artística.

\section{De profesión, pintora}

\section{[...] — ¿Cómo nació su afición?}

-Desde chiquita tuve gran entusiasmo por las obras de Arte, luego fui comprendiendo a Velázquez, en el Museo del Prado, hasta que tuve que pintar.

\footnotetext{
3 Vegue, 1924: 3 .

${ }^{4}$ La fortuna crítica de Marisa Roësset hasta la fecha ha sido escasa, destacando tan sólo los textos de CapdevillaArgüelles (2013: 115-139), y Peláez (2007: 90-95); a los que hay que sumar su presencia en apenas media docena de exposiciones colectivas: Mujeres en el arte español (1900-1984) I. Pintura y Escultura, catálogo, Madrid, Centro Cultural Conde Duque, 1984; Salón de la Asociación de Artistas Vascos, catálogo, Bilbao, Museo de Bellas Artes de Bilbao, 1986; Pintoras en España 1859-1926. De María Luisa de la Riva a Maruja Mallo, catálogo, Universidad de Zaragoza-Diputación de Zaragoza; y La Residencia de Señoritas en su centenario, catálogo, Madrid, Publicaciones de la Residencia de Estudiantes, 2015.

${ }^{5}$ En ese contexto, no es casual que de Rosario de Velasco, Margarita Frau, Marisa Pinazo, Eva Aggerholm y tantas otras artistas en activo durante estos años tan sólo conozcamos algunas de sus obras y ciertos detalles de su trayectoria, mientras que de algunas no sepamos ni esos detalles.
} 
—iQué escuelas ha frecuentado usted?

Estudié muchos años con Sotomayor; después fui dos más al estudio de Vázquez Díaz. Ahora trabajo en mi estudio particular, donde tengo también discípulas. Me divierte enseñar a ver la luz.

— ¿Cuándo y donde hizo usted la primera exposición?

—La primera fué en el "Lyceum femenino". Luego expuse en el salón de "Bibliotecas y Museos". —QQué distinciones ha recibido usted?

-En 1924 tuve por primera vez tercera medalla en la Exposición Nacional de Bellas Artes. Allí me adquirieron el cuadro, "Autorretrato", para el Museo de Arte Moderno. Luego, en la Exposición Internacional de Barcelona me dieron otra medalla y también adquirieron el cuadro para el Museo de allí.

— ¿Cuáles son sus aspiraciones?

-Esto me parece peligroso contestarlo, francamente.

Un apretón de manos rubrica la amena charla... Su técnica y su inspiración, nada vulgar, hacen de esta joven pintora una realidad del arte español y una gloria del femenismo ${ }^{6}$.

Así de escuetamente respondía Marisa Roësset en 1936 al preguntarle por su trayectoria, demostrando la firme convicción que mantuvo a lo largo de su existencia: ser mujer no le impediría ejercer su vocación, pronto convertida en profesión. Porque, desde una tempranísima edad se inclinó por la pintura, quizá influida por la figura de su tía, la también pintora María Roësset Mosquera, por quien tanto ella como su familia sentían un gran afecto ${ }^{7}$. En especial el padre de nuestra protagonista, quien apoyó los deseos de su hija desde el inicio. Un sostén esencial para cualquier mujer que, por aquel entonces, osase dedicarse a la creación ${ }^{8}$, del que también disfrutaron otras jóvenes pintoras como Maruja Mallo o Pitti Bartolozzi.

En consecuencia y pese a la misoginia que caracterizaba la época ${ }^{9}$, Marisa Roësset pertenece a esa escasa pléyade de creadoras que durante aquellos complejos y sugerentes años veinte y treinta arrostraron cuantos problemas fueron necesarios para realizar su trabajo. Sin arredrarse. Porque Marisa Roësset fue una de las escasas jóvenes que vivía con naturalidad la libertad que, entendía, merecía. Como cualquier varón.

En consonancia con semejante planteamiento, desde el principio apostó por una formación sólida y, como era usual entre los artistas, aprendió con destacados pintores — primero con Fernando Álvarez de Sotomayor, con cuya familia mantuvo una estrecha amistad, y después con Daniel Vázquez Díaz-; al tiempo que visitaba el Museo del Prado para contemplar las obras de los grandes maestros y proseguir su aprendizaje. Después pudo ampliar su formación en el extranjero, trasladándose a Italia gracias al apoyo que su familia siguió brindándole. Y a todo ello se sumó la información que consultó en las publicaciones artísticas a las que tuvo acceso.

Llama la atención, sin embargo, que precisamente en esos años no se matriculase en la Escuela Superior de Pintura, Escultura y Grabado de Madrid, el centro superior de formación en el que deseaban ingresar cuantos jóvenes aspiraban dedicarse a la creación. En especial, teniendo capacidad para ello y contando con la aquiescencia familiar. De nuevo, emerge Marisa Roësset como una personalidad distinta. Desconozco los motivos reales que la indujeron a ello, pero en semejante decisión debió influir el tristísimo suicidio de su hermano Mauricio — con el que mantenía una estrecha relación y al que retrató en numerosas ocasiones-, narrado por el poeta Rafael Alberti en el segundo volumen de La Arboleda perdida, tras el accidente de coche que tuvo con su pareja, la pintora Maruja Mallo, allá por $1926^{10}$. Un suceso que debió pesar tremendamente en el ánimo de la joven artista, y que —es sólo una opinión personal— propició tanto

${ }^{6}$ Jardel, 1936: 110-111.

7 Sobre la producción artística de su tía véase Maria Roesset (1882-1921), 1988.

8 Lomba, 2014: 50-69.

9 Sobre la misoginia en este universo artístico véase, por ejemplo: De Diego, 1987; Lomba, 2014: 54-59; y 2015 : 599-616.

${ }^{10}$ Mauricio Roësset mantenía relaciones con la pintora Maruja Mallo, y en una de sus escapadas nocturnas en automovil tuvieron un accidente. Al parecer Mallo quedó inconsciente y el joven, creyéndola muerta, escapó, acudió a su domicilio, se encerró en su dormitorio y se suicidó. Una suerte igualmente atroz corrió pocos años después su prima, la escultora Marga Gil Roësset. 


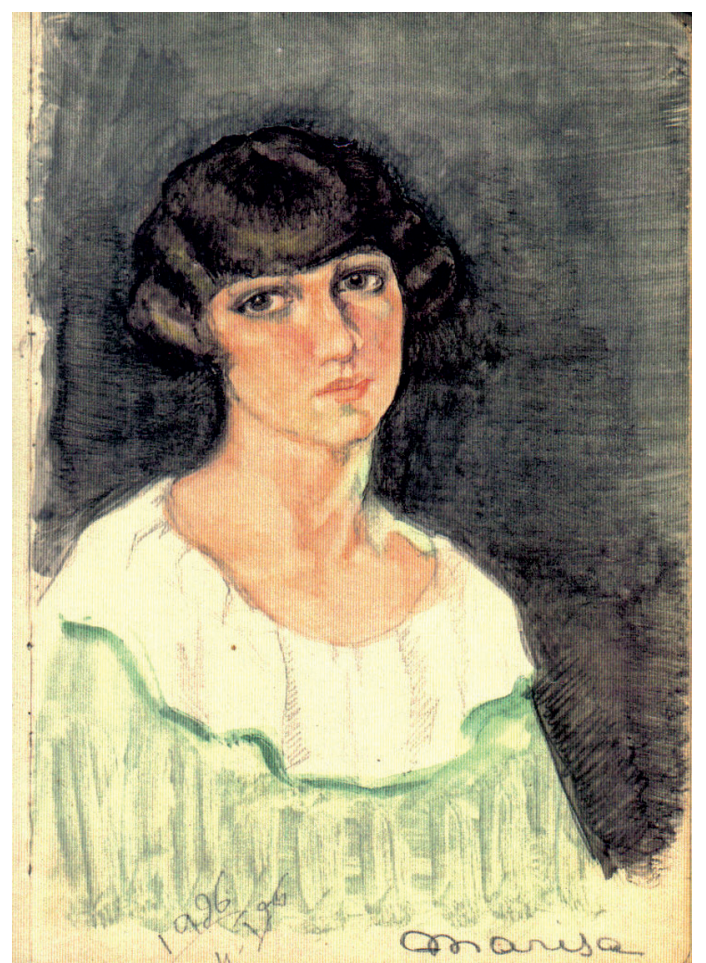

Fig. 2. Autorretrato, 1926, Madrid, Colección Ana Serrano su viaje a Italia para ampliar su formación ${ }^{11}$, como el que no deseara transitar las aulas que su hermano frecuentó, relacionarse con la gente que Mauricio conoció, ya que recientemente hemos descubierto que fue alumno de la mencionada Escuela. Y un suceso que explicaría, igualmente, la escasa relación que Roësset mantuvo con la propia Maruja Mallo, a quien conocía sobradamente y con la que compartía pasión por la pintura, aunque su forma de vida y su carácter fueran, presumo, bien distintos.

Ahora bien, aunque su formación no incluyera la Escuela Superior, su carrera profesional se desarrolló según los cauces establecidos por la cultura artística de la época. Y a pesar de su corta edad, en aquel lejano 1924 concurrió a la Exposición Nacional - el primer año, por cierto, que se celebró el certamen bajo la Dictadura de Primo de Rivera-, en la que como es de suponer la participación femenina fue escasísima, limitándose a una veintena de artistas entre las que se contaban Calvo Rodero, Durán, Pérez Herrero o Alcayde ${ }^{12}$. La tercera medalla que obtuvo, un galardón cotizadísimo y más para una mujer, le supuso una importante proyección.

A aumentar su difusión contribuyó la crítica que, contrariamente a lo que solía ser habitual en la época, no se prodigó con los consabidos comentarios de género $^{13}$, elogiando el lienzo exhibido de forma unánime. Así lo hizo uno de los mejores analistas del momento, José Francés, quien tras referirse a la escasa calidad de lo exhibido en la Nacional destacaba, empleando para ello su acostumbrado pseudónimo de Silvio Lago, la presencia de Roësset junto con la de "[...] Ribera, Durbán, Torres, Malinoska [...] Climent, y alguno más que involuntariamente parezca ahora inadvertido..."14. Al mismo tiempo, el lienzo fue reproducido en color y a página completa en La Esfera, una de las revistas culturales más prestigiosas del momento. Una repercusión similar alcanzó en la Nacional de 1926 - recuerde el lector que estos certámenes se celebraban con carácter bianual-, a la que concurrió con dos lienzos: Mi hermano y yo y Hanny $y$ Gucki (fig. 2) ${ }^{15}$. Ambos fueron nuevamente destacados por la crítica, en un tono tan respetuoso como el empleado por Méndez Casal desde la influyente Blanco y Negro, en la que resaltó su "[...] fuerte temperamento artístico, $[\ldots]$ una técnica de vanguardia $[y]$ una fina espiritualidad... $" 16$.

Marisa Roësset demostraba que su vocación no era una afición y logró escalar el siguiente peldaño en esa suerte de cursus honorum que todo artista debía cumplir: celebrar una exposición monográfica, un sueño difícil de conseguir para cualquier creador y mucho más si se trataba de una mujer; de hecho por aquellas fechas fueron muy pocas quienes consiguieron semejante proe-

11 Marisa Roësset no fue la única que abandonó temporalmente aquel Madrid que tanto le recordaba a su hermano, pues Marulla Mallo también se trasladó por las mismas fechas a las islas Canarias.

12 Exposición Nacional de Bellas Artes. MCMXXIV. Catálogo Oficial ilustrado.

13 Sobre las consideraciones de género en las críticas artísticas aparecidas en estos años: Lomba, 2014: 56-59.

14 Lago, 1924.

15 El Autorretrato de 1926 pertenece a la colección de la sobrina y biógrafa de la pintora, Ana Serrano, a quien agradezco que me mostrase las obras que conserva.

16 Mendez, 1926: 28.

Archivo Español de Arte, vol. XCI, n. ${ }^{\circ} 362$, pp. 143-158, abril-junio 2018 ISSN: 0004-0428, eISSN: 1988-8511, https://doi.org/10.3989/aearte.2018.10 
$\mathrm{za}^{17}$. Fue así como en enero de 1927 presentó su primera individual en el recién inaugurado Lyceum Club madrileño ${ }^{18}$, exhibiendo veintiuna obras fechadas entre 1922 y 1926: Cabeza de gallega, La acequia y La Casita del pobre datadas en 1922; Ciochara de 1923; Agustina, Abulense y La Lección pintadas en 1924; Rezando el rosario, Retrato de Walburga Wortmuller, La modistilla, Naturaleza muerta y La terraza en 1925; y en 1926 las restantes: Retrato del Doctor Benavente, Estudio, Marinero vasco, Cesta de frutas, Campesina de Ávila, Naturaleza muerta, Autorretrato y dos tituladas Balcón ${ }^{19}$. Y logró un rotundo éxito tanto artístico como social a juzgar por los comentarios que se le dedicaron, en los que en esta ocasión no faltaron los habituales elogios a su belleza con palabras como "Joven, grácil, gentilísima, con una bella prestancia... Marisa Roësset une a la pimpante gracia de su belleza, la gracia reflexiva, serena, madura de su arte..."20.

Tras la clausura, un tiempo de silencio parece que se cernió sobre ella. Sin embargo, no dejó de trabajar, siguió ensayando nuevas formulaciones pictóricas hasta que, a fines de 1928, reemprendió sus presentaciones públicas. En octubre de aquel año participó en una muestra colectiva dedicada a los "Autorretratos", siendo la única participante entre un colectivo de renombrados artistas como Gutiérrez Solana, Hermoso, Piñole, Prieto o Souto ${ }^{21}$. Y en 1929 no sólo acudió a dos importantes colectivas - la Exposición Internacional de Barcelona y el Salón de Otoño-, sino que expuso, nada más y nada menos, que en el Museo de Arte Moderno. En la Internacional de Barcelona, convertida en uno de los mejores escaparates para cualquier artista, exhibió Reposo y logró otra tercera medalla que, además, implicaba la adquisición del lienzo para el Museo de Arte Moderno de Cataluña. Con semejante galardón había conseguido en un quinquenio lo que la mayoría de los artistas ansiaban: su representación en las colecciones de los dos museos de arte contemporáneo españoles más importantes. En octubre de aquel mismo 1929 concurrió al Salón de Otoño con Campesinos de Ávila, una pintura en la que introdujo ciertas novedades estéticas $^{22}$. Y el año no pudo concluir de mejor manera, pues exhibió una importante selección de su producción artística en el madrileño Museo de Arte Moderno junto a Gisela Ephrussi, que le valió juicios favorables desde todos los sectores de la crítica. Pocas mujeres habían conseguido semejante proeza: Marisa Roësset proseguía imparable su ascensión artística.

Los años treinta - aquella década que, desde un punto de vista histórico, emergió triunfante- fueron sucediéndose con un ritmo expositivo vertiginoso hasta el estallido de la guerra civil. Durante aquel quinquenio acudió a las Exposiciones Nacionales de 1930, 1932, 1934 y 1936 con una pintura de carácter religioso que consiguió elogiosos comentarios. Y al tiempo se produjeron tres hechos harto significativos en su trayectoria profesional que conviene destacar.

El primero refrenda el carácter fronterizo de nuestra protagonista y constituyó una novedad importante en aquella pacata sociedad española. Me refiero a la apertura de la Escuela de pintura que regentó - quizá en colaboración con sus compañeras de estudio: Pilar y María del Carmen Alvárez de Sotomayor ${ }^{23}$ - y que debió inaugurar estrenada ya la II República pues, pese a lo que se ha escrito y como ya publicamos hace algún tiempo, el 18 de diciembre de 1932 el Estudio fue ensalzado en un reportaje aparecido en el prestigioso periódico El Sol aludiendo a la modernidad de la maestra y sus discípulas con estas palabras:

17 Entre las artistas que lograron exponer individualmente en aquellos años destacan: Maruja Mallo, que se presentó en los salones de la Revista de Occidente un año más tarde que Roësset, o Ángeles Santos que hizo lo propio en las salas del Lyceum Club madrileño en 1929.

18 Sobre la historia del Lyceum Club puede consultarse el catálogo Mujeres en Vanguardia, 2015. Entre las actividades llevadas a cabo destacan las exposiciones temporales que, sin embargo, fueron objeto de duros comentarios en las Memorias publicadas por Carmen Baroja, aunque no alude a Roësset de forma específica. Baroja, 1998: 90.

19 Murga, 2015: 102-111.

20 R. M., 1927: 4.

21 "Colectiva Autorretratos". En El Heraldo de Madrid, Madrid, 24-X-1928: 7.

22 Catálogo del noveno salón, 1929.

23 CIL, "De la vida moderna. Chicas de hoy", El Sol, 18-XII-1932, p. 6. La cita ha sido tomada de Lomba, 2015: 601. 
“[...]Fuera hace frío; pero aquí en el estudio emana un calorcillo grato de estufa encendida[...] en las paredes blancas, lienzos y más lienzos[...] En torno nuestro, chicas de uniforme. De un uniforme caprichoso y personal. Delantales de hilo. Verdes. Azules. Rojos. Cuellos altos y mangas jamón. En torno nuestro, rostros juveniles con el ceño fruncido por la aplicación. Caballetes. Lienzos. Paletas. Pinceles. En el centro, un bebé rubio que es meta de todas las miradas[...] de estas muchachas muy 'al día', que comprendiendo bien el sentido de la frase moderna de 'adórnate con los resplandores de tu Inteligencia cultivada, de tu ciencia, de tu arte', estudian pintura bajo la dirección solícita de esa joven maestra del pincel que es Marisa Roësset. ¡Muchachas modernas! No Vírgenes locas de films americanos [...], sino vírgenes prudentes, producto de una generación que quiere 'bastarse a sí misma’. ¡Muchachas modernas! No sólo cuerpos flexibles, diestros en todos los deportes, sino espíritus flexibles también, inteligencias abiertas de par en par a todo lo que pueda elevarlas. ¡Bello ejemplo las discípulas, con su empeño, con su empuje, con su ambición noble de saber y admirable ejemplo; esa directora de cabeza de arcángel y ojos de luz que anima aquí, corrige allá [...]"24.

El éxito de la Escuela — en la que se formaron gentes como la afamada Menchu Gal—, fue tal que se mantuvo en activo durante más de treinta años. Y su apertura debió inducirle a matricularse, al fin, en la Escuela Superior de Pintura, Escultura y Grabado; el segundo asunto de importancia al que me refería. Ocurrió en 1934, cuando ya había cumplido los treinta y un años y era una figura consolidada en el panorama nacional. En su expediente ${ }^{25}$ consta que se inscribió, tras haber demostrado su preparación ${ }^{26}$, primero como alumna libre en la asignatura de Perspectiva ${ }^{27}$; después, de forma oficial ese mismo curso de 1934-1935, en Anatomía e Historia del Arte $\left(1\right.$ curso ${ }^{28}$; y el curso siguiente en Historia del Arte 2 y Geometría Descriptiva ${ }^{29}$. La guerra civil impidió que completase sus estudios, que retomó en 1939 una vez concluida. De hecho el 15 de febrero de 1939 Marisa Roësset volvió a matricularse en un par de asignaturas: Teoría de las Bellas Artes y Métodos y procedimientos de enseñanza del dibujo. Contaba entonces con 35 años, según rezaba el resguardo de la matrícula, en el que probablemente se base el error reiterado en su fecha de nacimiento ${ }^{30}$, cuya partida hemos hallado y explicita concretamente no sólo su nombre completo — Luisa, María Victoria, Hispania—, que jamás empleó, sino también que "[...]la dicha niña nació en la casa del declarante a las 8 del día seis del actual[...]", habiendo hecho notar que se firmaba el nueve de marzo de 1903.

Aquel 1934 trajo consigo otro asunto relevante pues Marisa Roësset celebró su tercera muestra individual en las salas que la prestigiosa Asociación de Artistas Vascos tenía en Bilbao. Organizada a través de las relaciones que mantenía con los Urrutia, su presencia artística en el País Vasco aquel mes de agosto debió suponer un gran acontecimiento personal y profesional, pues exponía en una tierra muy querida — su madre nació en Vitoria—, con la que mantenía una estrecha relación, logrando los parabienes de la crítica $^{31}$. Entre la veintena de obras expuestas destacó Reposo, el lienzo galardonado en la Internacional de Barcelona ${ }^{32}$.

${ }^{24}$ CIL, 1932: 6 .

${ }^{25}$ La consulta de la documentación ha sido una tarea grata gracias a los profesionales que integran los Archivos de la Universidad Complutense de Madrid. En especial Ana Rocasolano, Isabel Palomera y Amelia Valverde, a quienes agradezco su trabajo y amabilidad.

${ }^{26}$ Habitualmente quienes deseaban matricularse en la Escuela Superior debían aportar el certificado médico, como así hizo Roësset, y un documento que avalase los estudios relizados. La pintora presentó el resguardo de la tercera medalla conseguida en la Nacional de 1924, fechado el 11 de mayo de 1934. Expediente académico de L. Roësset y de Velasco. Archivo General Universidad Complutense de Madrid (A.G.U.C.M.), sig. 136/06-05,19.

27 Expediente académico de L. Roësset y de Velasco, 11, mayo, 1934. A.G.U.C.M., sig. 136/06-05,19.

${ }_{28}$ En el resguardo de la matrícula llama la atención que se cite el domicilio materno y la edad de 30 años. Expediente académico de L. Roësset y de Velasco. A.G.U.C.M., sig. 136/06-05,19.

${ }^{29} \mathrm{La}$ inscripción en ambas materias se formalizó el 2 de octubre de 1935. Expediente académico de L. Roësset y de Velasco. A.G.U.C.M., sig. 136/06-05,19.

${ }^{30} \mathrm{La}$ fecha de nacimiento repetida por los diferentes autores hasta este momento es la de 1904. Sin embargo, su sobrina Ana Serrano me explicaba ya en 2014 que estaba equivocada y, por fortuna, la documentación que he podido consultar en el A.G.U.C.M avala fehacientemente que nació en 1903.

31 C. L., 1934.

32 Mur, 1985: 168. 


\section{La moderna figuración de Marisa Roësset}

Aquel hermoso y sincero Autorretrato con el que Marisa Roësset - el nombre elegido para firmar sus obras - se presentó a la Nacional de 1924 semeja una declaración de intenciones, decía, también en el terreno estético.

Recuerde el lector que hasta la fecha fueron pocos los artistas varones que, en su primera comparecencia pública eligieron su propia imagen. Sin embargo, nuestra protagonista no dudó en hacerlo, demostrando su modernidad y la preferencia que mantuvo a lo largo de su trayectoria tanto por sus representaciones como por las de sus seres más queridos, a quienes recreaba de forma monumental ocupando todo el espacio pictórico. Marisa Roësset se inserta, pues, en esa constante iconográfica que caracterizó a las artistas a partir de 1914, quienes, como mantenía hace algún tiempo, sustituyeron las consabidas flores por imágenes procedentes de su entorno personal ${ }^{33}$. Esa tendencia fue asumida gustosamente por la nueva generación de artistas modernas a la que pertenecía Roësset, siendo precisamente ella una de las más proclives a los autorretratos y una de las más sensibles también a la representación de los asuntos que podríamos considerar de género. Tanto como Ángeles Santos, por ejemplo, aunque ambas los ambientaran en espacios y atmósferas bien distintos. Por contra, los paisajes - habituales también entre la producción de otras pintorasy las naturalezas muertas fueron asuntos escasos en su repertorio icnográfico desde sus inicios.

Para concebir tan sugerente Autorretrato - magníficamente recibido por la crítica y por el Jurado que lo premió-, empleó una figuración avanzada ejecutada con una pincelada suelta y una moderna gama cromática de colores fríos y delicados matices que casi superaba el lenguaje de su maestro, el pintor Álvarez de Sotomayor con quien, por cierto, dibujó las preceptivas "academias" que cualquier alumno debía realizar. Su resuelta y sugerente imagen constituyó un grato y prometedor preludio de su trayectoria artística.

Desde entonces sus indagaciones estéticas avanzaron a pasos agigantados; en especial, desde 1925, año en el que ya debió acudir a las clases de Daniel Vázquez Díaz, considerado por Alberti como el mejor revulsivo artístico de la capital, tal y como recordaba en sus Memorias:

[...]En el ambiente pictórico aburrido y academizante del Madrid de aquellos años, la aparición de Vázquez Díaz sirvió de revulsivo, de agitado despertador para los jóvenes. Y, aunque no fuera un revolucionario de primera avanzada, sus dibujados retratos, simples de líneas y sugeridos planos, su pintura, de procedencia cézanniana en la técnica, pero de un fuerte espíritu español, fueron como una brecha abierta al aire, libertadora entrada para nuevos experimentos $[\ldots]^{34}$.

En efecto, desde 1925 el lenguaje de Marisa Roësset se adscribió a esa moderna figuración que se difundió entre los jóvenes creadores españoles, tras la célebre muestra de la Sociedad de Artistas Ibéricos inaugurada al mediar aquel año en el madrileño Palacio del Retiro. Convertida en la bisagra en torno a la que se vertebraron las tendencias artísticas más avanzadas, en la Exposición confluyeron los nuevos realismos de Dalí y Barradas con la figuración de los artistas vascos y con la patente influencia de Vázquez Díaz que, aunque ausente de la exhibición, dejó sentir su eco entre los participantes ${ }^{35}$. Fue precisamente esa moderna figuración, con matices que la diferencian de los nuevos realismos, la que situó a Marisa Roësset de nuevo en una zona fronteriza; ahora estéticamente.

Una figuración en torno a la que experimentó sin denuedo, especialmente durante la primera etapa de su producción que, en mi opinión, debe fecharse entre 1925 y 1930, y que puede considerarse como la época más importante de su trayectoria artística.

En esa búsqueda permanente, puesta de manifiesto por cuantos críticos se acercaron a su trabajo $^{36}, 1925$ fue un año especialmente productivo pues, bajo la perceptible influencia de Váz-

\footnotetext{
33 Lomba, 2014: 59-64.

34 Alberti, 1994: 65.

35 Brihuega, 1995: 15-31.

${ }^{36}$ Llama la atención la sinceridad con que Milagros S. C. analiza la producción de la pintora, en la que alude constantemente a su búsqueda de la perfección. En S. C., 1927: 4.
} 


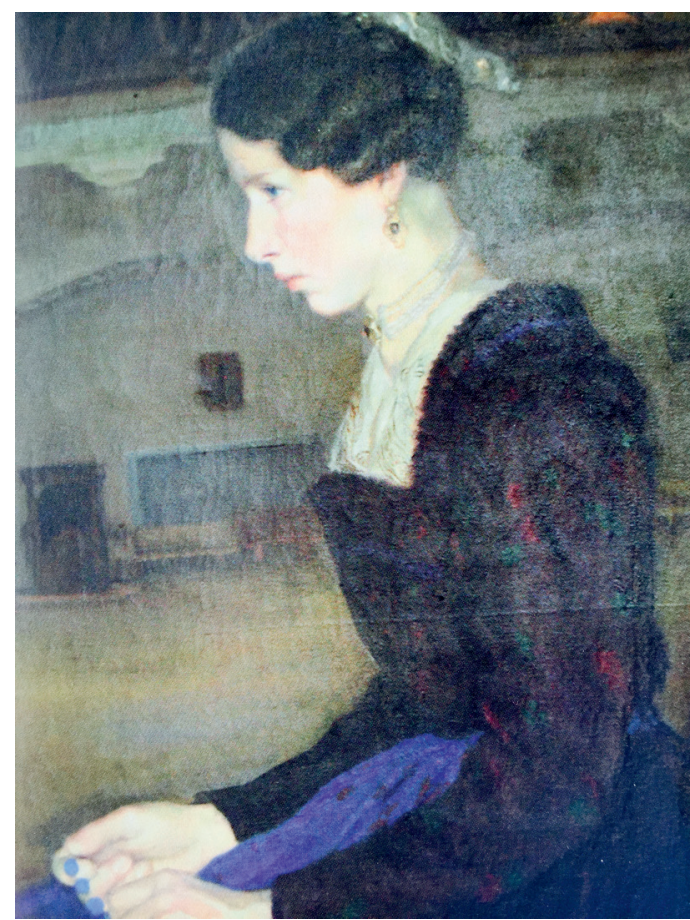

Fig. 3. Rezando el rosario, 1925, Madrid, Colección M. Rodríguez

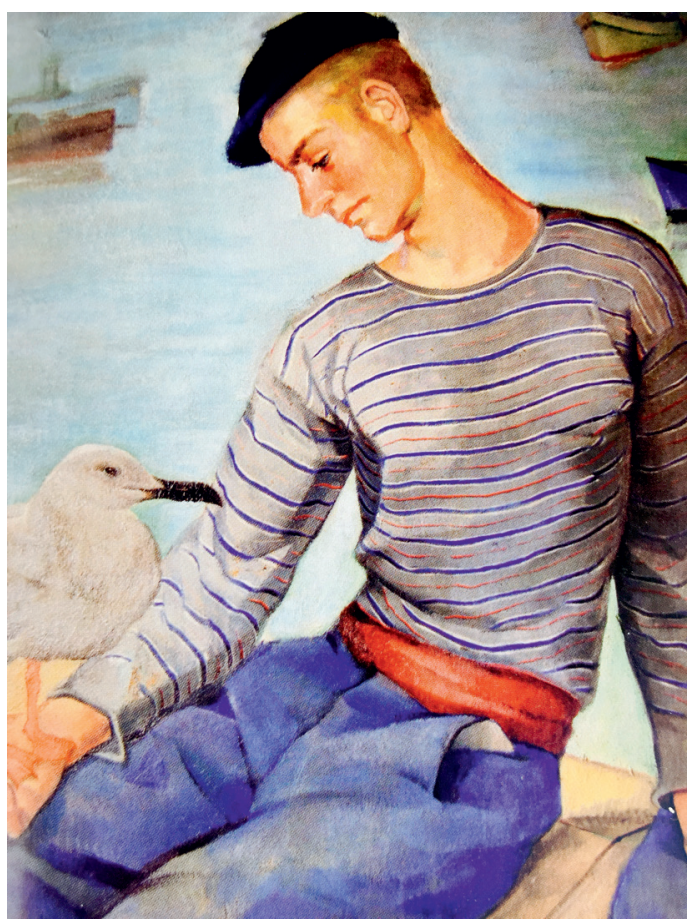

Fig. 4. Marinero vasco, h. 1925, Madrid, Colección M. Rodríguez

quez Díaz, ensayó formulaciones diferentes que pueden organizarse en cuatro grupos distintos. En el primero destacan algunos paisajes y otros lienzos de envergadura protagonizados tanto por ella como su hermano Mauricio. Me refiero a Autorretrato como cazadora y Retrato de su hermano como cazador, firmados y fechados en aquel feliz 1925, cuyas imágenes aparecen en medio de un frondoso paisaje similar a los concebidos por Vázquez Díaz desde fines de los años diez $^{37}$. Similar tanto en la gama cromática empleada - los verdes y azules cezannianos que Vázquez Díaz reelaboró, junto con sus característicos grises y violas-, como en los trazos rápidos, intensos perfiles y escasa capa pictórica que la discípula utilizó.

Influida igualmente por su maestro, Roësset compuso un segundo grupo de obras representando a lugareños españoles, casi siempre mujeres, una tendencia que, dicho sea de paso, se había convertido casi en una moda por aquéllas fechas. Pareja de aldeanas con pollo, un lienzo firmado y fechado en aquel año, muestra una singular pareja de campesinas, ataviadas con los trajes típicos, que parece se encaminan a visitar a alguien. La escena, que se desarrolla en medio del camino, bajo un hermoso y pálido atardecer, recuerda ciertas pinturas de Vázquez Díaz como Les deux spagnoles, fechada hacia 1910. En esa misma línea, aunque con un escenario mucho más construido, como también hiciera Vázquez Díaz al cambiar de década, destaca Rezando el rosario (fig. 3), una hermosa obra datada ese 1925, en la que tanto la luz como la quietud del ambiente casan a la perfección con la actitud melancólica de la protagonista: una joven que, vestida con ropa festiva, inclina levemente su rostro para rezar el rosario.

Mucho menos interesante pareció a la crítica el último conjunto de pinturas que Roësset ensayó durante aquel 1925. Me refiero al integrado por obras como Hanny y Gucki, expuesto en la Nacional de 1926, una pieza realmente sobresaliente que, alejada de la estética de Vázquez Díaz, fue considerada "[...]más conservadora" 38 . Imagino que las influencias de los maestros flamen-

37 Sobre Vázquez Díaz véase el estudio de Brihuega/ García, 2005.

38 García de Valdeavellano, 1926: 1. 


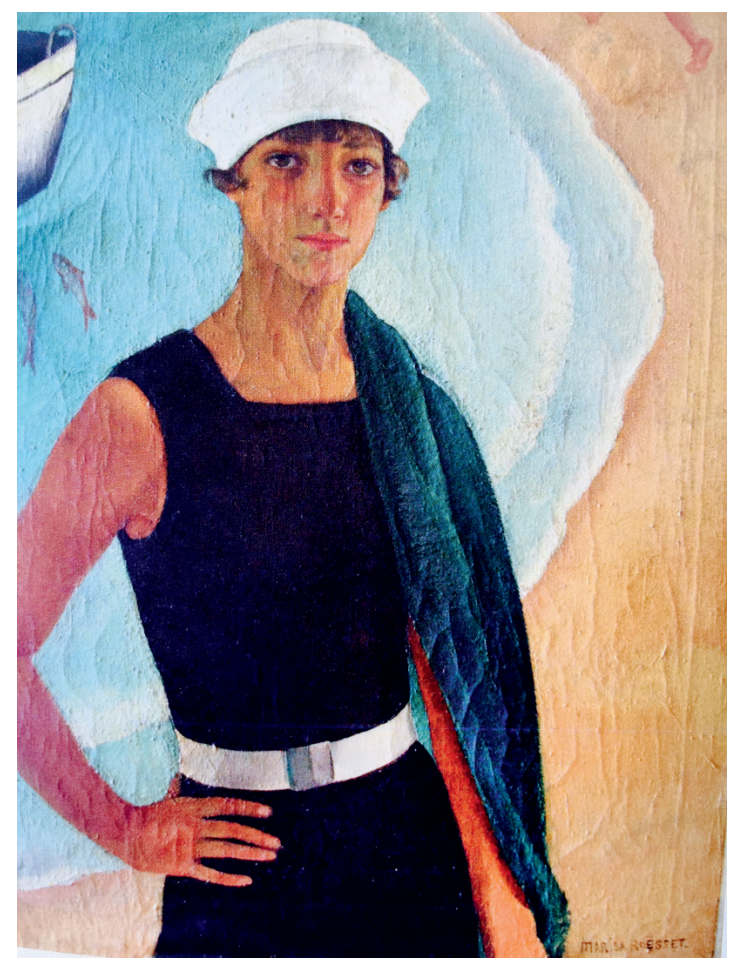

Fig. 5. Autorretrato en la playa, 1925, Madrid, Colección Ana Serrano

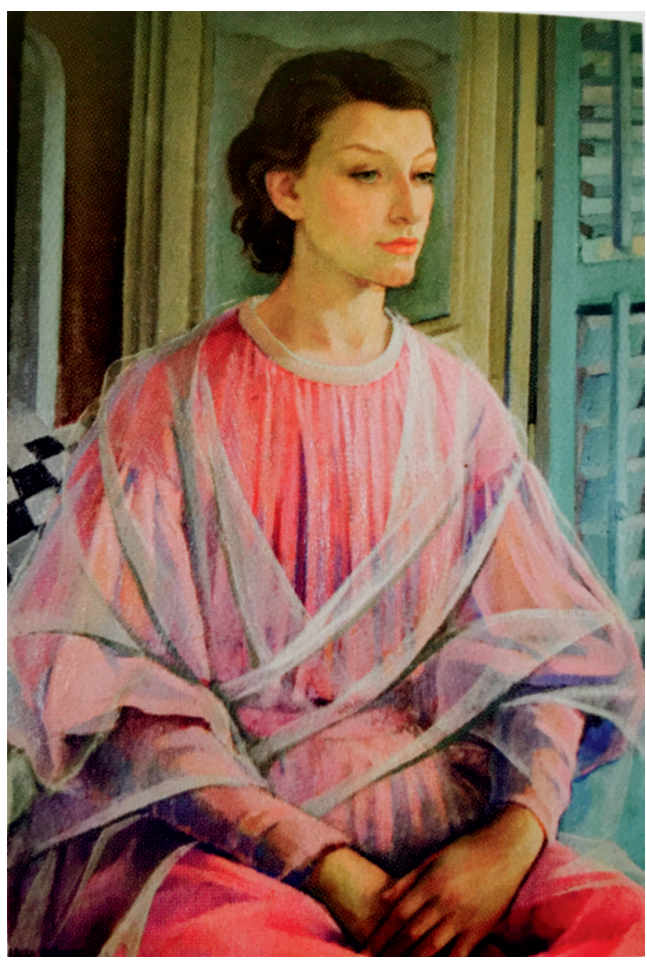

Fig. 6. Balcón, 1926, Madrid, Colección M. Rodríguez

cos y ciertos resabios simbolistas no fueron entendidas por un amplio sector de la crítica. Todo lo contrario que hicieron comentaristas tan avezados como José Francés, quien un año antes elogió un lienzo de Ortiz Echagüe con el que concurrió a la Nacional de 1924, titulado Jacob van Amstel en mi casa, que debió influir en el compuesto por Roësset ${ }^{39}$.

Pero sus ensayos formales no habían concluido todavía aquel año pues durante el verano experimentó con otro vocabulario, influido igualmente por Vázquez Díaz (fig. 4), en el que destaca su Autorretrato en la playa, una escena casi idílica, junto al mar, en la que Marisa Roësset volvió a representarse frente al espectador, de forma decidida, como ya hiciera en 1924 (fig. 5). Y como entonces, se retrató como un mujer moderna, luciendo su torso en traje de baño: con esos característicos bañadores que se pusieron de moda en España y Europa entre un selecto grupo de jovencitas que podían disfrutar del mar, y que también Maruja Mallo representó en alguna ocasión. Su nuevo Autorretrato se me antoja otra declaración de intenciones, sólo que concebido con un vocabulario distinto: a base de una reducida y contrastada paleta de colores y una escasa capa pictórica de perfiles duros y rápidos, con la que construyó un singular — casi surreal- mar, intensamente azul y alegre, con peces saltando felices junto a las barcas que se insinúan en el horizonte. Y sobre tan bucólico escenario, de superficies planas, se recorta, decidida y dulce la joven pintora.

Tan sugerente y acertada producción le valió, al año siguiente, críticas personales y profesionales muy injustas. Las relativas a la denostada influencia de su maestro Vázquez Díaz fueron especialmente duras y provenían de la crítica más conservadora, aunque también las hubo más discretas como la publicaba por Domenech quien afirmaba: 1926.

${ }^{39}$ Como decía en páginas anteriores José Francés empleó, por estas fechas, el pseudónimo de Silvio Lago. Lago, 
[...] creo que la señorita [...] está aún en los años de aprendizaje [...] lo que si tiene de particular [...], es la preocupación de querer colocarse en el plano de la vanguardia, y mientras pinta sus figuras, las frutas y objetos inmediatos, como hubiera podido hacerlos en los buenos tiempos Luciano Simon, pinta el fondo de paisaje de tal modo estilizado, que bien podría servir de modelo para una mantelería de té [...] [aunque también añadía que revelaba] excelentes condiciones de pintora $[\ldots]^{40}$.

Más insidiosos fueron los juicios relativos a su comportamiento, a su forma de vestir. Parece que el tiempo no hubiera transcurrido y que, tal y como había sucedido históricamente, las artistas volvían a ser merecedoras de frívolos comentarios de género. Entre los peores destaca el de Rodenas, quien primero afirmaba que seguramente era "[...] una muchacha bellísima, que tiene mucho talento y por añadidura elegante [...]" para, a continuación, exponer los problemas que aquejaban a su quehacer artístico y que cifraba en:

[...] ese prurito de elegancia la obliga a adaptarse a la última moda, y eso, que sin duda en cuanto al atavío personal - más en una mujer - añade gracia al rostro y encanto a la figura, en otras aplicaciones, en todas las de orden espiritual, perjudica. No olvidemos que la moda tiene carácter pasajero, tornadizo, de constante renovación. En moda no sirve lo de ayer; lo de hoy agoniza; hay que acertar con el primer minuto de mañana. $\mathrm{Y}$ en arte, al revés que en el mueble y el vestido, el anhelo de perfección tiende a lo perdurable, a lo eterno [...] Ha sido sucesivamente discípula de [...] Álvarez de Sotomayor, excelente maestro; [...] López Mezquita, admirable pintor; y [...] Vázquez Díaz, último figurín de la elegancia pictórica $[\ldots]^{41}$

Por fortuna, semejante pléyade de comentaristas no habían contemplado todavía algunas obras que la artista pintó influida por diferentes corrientes estéticas que pudo contemplar en su estancia italiana. Me refiero a esos dos hermosos autorretratos, fechados en 1926, en los que Marisa Roësset aparece sentada y de pie respectivamente en un balcón. En ambos lienzos va ataviada como si se tratara de una romana clásica — con una suerte de túnica rosa intenso, sobre la que se desliza un chal blanco transparente-; peinada con su ya clásica corta melena, que permite contemplar su rostro anguloso y perfecto de mejillas apenas sonrosadas; y contemplando la calle, en una serena y fría actitud (fig. 6). Aunque quizá fuera mejor decir que parece estar contemplando el paso de la vida. La hermosa joven semeja una patricia romana que muy bien pudiera haber sido pintada por aquel fascinante Masaccio — revisitado- o por los más conspicuos representantes del novecento italiano.

Todas estas obras y alguna más hasta sobrepasar la veintena fueron exhibidas, como decía en páginas anteriores, en su primera exposición individual instalada en el Lyceum Club en enero de 1927 que se convirtió en todo un acontecimiento social pues no en vano la pintora pertenecía a una familia acomodada ${ }^{42}$. A su inauguración acudió la sociedad madrileña más selecta: “[...] entre las damas que forman la Sociedad, orgullosas de dar acogida empresa de tanto valor espiritual como la exposición de la señorita Roësset, y despertó entre los artistas consagrados expectación enorme pues la linda expositora ya había tenido heraldos de su fama. Por eso, entre la distinguida concurrencia, vimos al Director general de Bellas Artes, al Sr. Sotomayor, que dirige la Academia de San Fernando [...]"43. Y la crítica inteligente elogió su trabajo y consideró las obras modernas y de calidad: "[...] Ha reunido la señorita Roësset una colección de sus obras en las que claramente pueden apreciarse las grandes condiciones de que está dotada y su fina sensibilidad artística. En sus cuadros se aprecian los avances realizados en la orientación y en la técnica, cada vez en un sentido de mayor modernidad en el acento, certeramente definido" 44 .

40 Domenech, 1926: 3.

41 Diario Universal, 12-VI-1926: 1.

42 “[...] Se ve muy concurrida en estos días la Exposición de otra artista también joven, bella y aristocrática: Marisa Roësset, que ha presentado en el Lyceum una serie de cuadros verdaderamente notables[...]". Danceny, 1927.

43 "El Club femenino. Exposición Marisa Roësset”. En: El Sol, Madrid, 11-I-1927.

44 "Notas de Arte. Inauguración de la Exposición de la señorita Marisa Roesset en el 'Lyceum”", La Época, Madrid, 11-I-1927, p. 2. 
Las criticas debieron animar a Roësset, quien entre 1927 y 1929 prosiguió con sus investigaciones a un ritmo tan vertiginoso como el seguido hasta la fecha. Sin tregua ni concesiones a los maliciosos que alababan su belleza, mientras criticaban su modernidad y elegancia. Una elegancia que parecía preocuparles porque, en mi opinión, la identificaban con la estilización y la quietud que caracterizó su producción artística, dos rasgos también presentes en los nuevos realismos europeos. Ambas premisas, junto con los colores grises, violáceos y las luces vaporosas y frías de las que se sirvió definieron su lenguaje; todavía muy próximo al de Vázquez Díaz. Al igual que sus frecuentes pinceladas de vivas aristas y perfiles secos y bruscos que, sin embargo, en ocasiones se tornaban sutiles, casi etéreas.

Esa quietud impregna uno de sus mejores y más ocurrentes autorretratos, un divertimento pictórico de gran calidad. Me refiero a su Autorretrato tumbada en el suelo, firmado en la propia paleta y fechado en 1927 (fig. 7), en el que se representó tumbada en el suelo, con la paleta en una mano y el pincel en la otra justamente en el instante en que contempla el paisaje para seguir pintando el

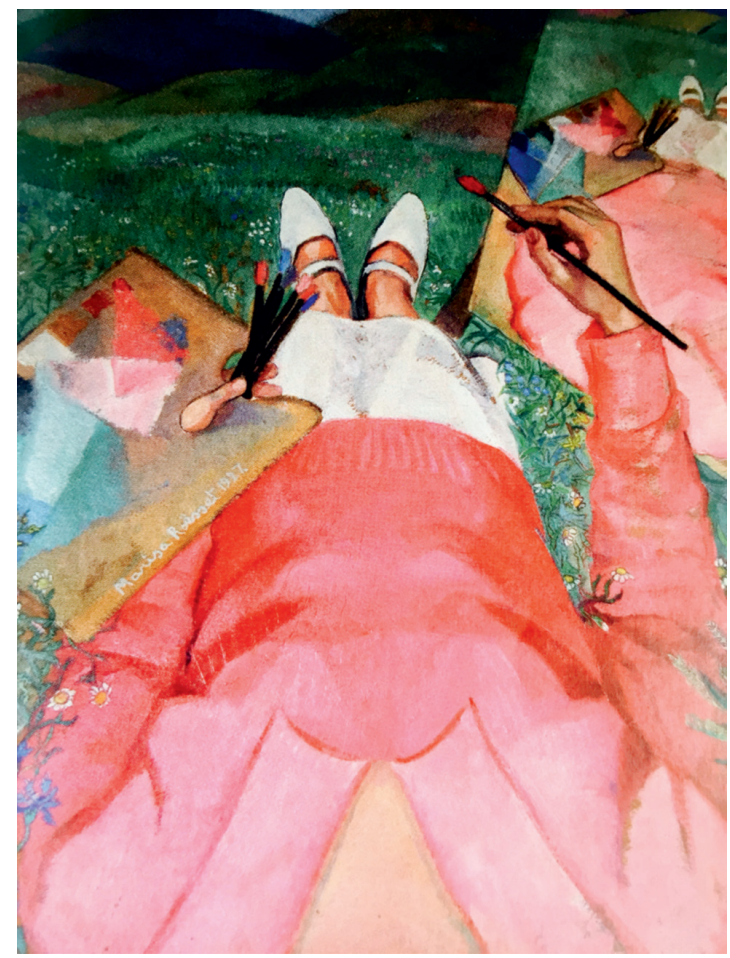

Fig. 7. Autorretrato tumbada en el suelo, 1927 , Madrid, Colección M. Rodríguez lienzo situado junto ella. Tan ingeniosa postura y singular perspectiva permite al espectador contemplar a la protagonista $\mathrm{y}$, al unísono, disfrutar de las suaves colinas de franjas verdes, rojas y violas, de perfiles precisos que contrastan vivamente con el fresa y blanco de su moderno atuendo.

Semejante estallido de color apenas duró el tiempo invertido en pintar aquel lienzo, porque la artista siguió fiel a sus tonos fríos y grises, como los empleados en los retratos de su hermano Mauricio, al que representó solo o en compañía del hijo de Álvarez de Sotomayor. De entre los conservados, uno de los más sentidos es el que aparece recortado sobre un infinito paisaje, vestido con un traje regional y con un bastón en la mano; una obra estrechamente vinculada con el Retrato de Geoffrey Sampson pintado por Fleetwood-Walker en 1922. Sin duda que Roësset debió conocer la producción del inglés porque su influencia se percibe en algunas otras representaciones de su hermano. Por ejemplo cuando - tras retratarlo vestido de campesino en compañía del hijo de Sotomayor (fig. 8) - , los pintó ataviados con sendos trajes blancos en La isla misteriosa o La isla del tesoro. La obra reviste una gran importancia icónica pues los jóvenes fueron retratados en sus vacaciones estivales, tendidos sobre la hierba mientras dejan vagar su imaginación al contemplar el mapa que, quizá, les informe de la isla misteriosa novelada por Julio Verne, cuyo ejemplar aparece a su lado. La sensación de felicidad percibida es similar a la que disfrutan los protagonistas de otras obras fechadas por la misma época, ya que fue un asunto relativamente frecuente entre los creadores más avanzados. Entre otros, José de Togores, quien recreó imágenes similares en Pareja en la playa y Niños durmiendo, fechados respectivamente en 1922 y 1927; Rosario de Velasco — otra de las pintoras que protagonizaron la escena artística española durante los años treinta- que compuso un sugerente canto a la libertad en 1932 en su galardonado Adán y Eva; o el citado Bernard Fleetwood-Walker, quien en 1933 pintó Amity, cuya relación con el Adán y Eva de Velasco es más estrecha todavía pues la pareja representada son una mujer y un hombre.

Por las mismas fechas, la característica gama gris y violeta y una atmósfera silenciosa y melancólica definieron algunos hermosos retratos como el de Leonor Urrutia y Mujer en azul 


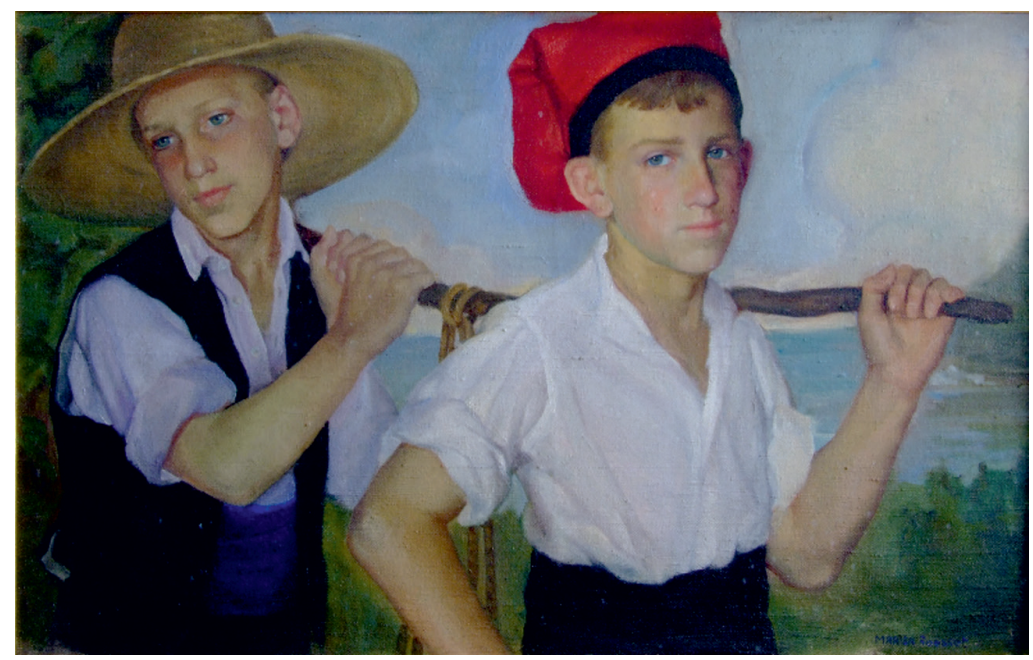

Fig. 8. Mauricio y su amigo, h. 1928, Madrid, Colección C. Rodríguez

-1928 - (fig. 9), dos jóvenes de miradas tristes que contemplan fijamente al espectador o, quizá, a la pintora, recortadas — como era habitual en la producción de Roësset— sobre espacios neutros o sobre nostálgicos paisajes propios del País Vasco. Ocurre con el de Leonor Urrutia que, ataviada con una falda y una camisa sencilla, interrumpe su lectura en el instante en que fue inmortalizada para la posteridad. Tanto su atuendo, ejecutado a base de pinceladas facetadas que recuerdan a Vázquez Díaz, como la ausencia de adornos aumenta ese cierto carácter varonil que, en mi opinión, poco tiene que ver con la corriente del dandismo pictórico al que alude Nuria Capdevila-Argüelles como una de las constantes estéticas de la creadora. Tan sólo los retratos de la pintora romana Romaine Brooks - 1874-1970 - mantienen ciertas relaciones con algunos de los concebidos por Roësset Velasco, quien debió conocer sus trabajos a través de alguna publicación. Porque lo que no cabe ninguna duda es que nuestra protagonista estaba bien informada sobre las novedades artísticas europeas.

Semejantes premisas estéticas y compositivas caracterizan otro de sus hermosos retratos, Reposo, galardonado en la Internacional de Barcelona de 1929 (fig. 10). Solo que la protagonista - posiblemente la artista, que ya se había representado como cazadora años atrás - nos contempla desde un frondoso paisaje de enormes cactus en el que nuevamente se percibe la influencia de Vázquez Díaz; eso sí con un cigarrillo en la mano, a la manera de las evas modernas que por aquellas fechas caracterizaban el imaginario artístico europeo.

Igualmente sorprendente es otro lienzo pintado por las mismas fechas, intuyo que hacia 1928 , que por desgracia se encuentra en paradero desconocido. Me refiero al titulado Gitana, una obra que responde al gusto que la pintora sentía por inmortalizar a los lugareños españoles; al igual que otra de las mejores artistas de la época: Delhy Tejero que, como Roësset, optó por una moderna figuración como lenguaje estético esencial. Sólo que la Gitana de nuestra protagonista - una figura de carácter monumental que contempla fijamente al espectador - aparece sentada en el interior de su cocina. Se trata de una escena similar, aunque de mayor calidad, a la pintada por Luisa de Urcola por esas mismas fechas y que presentó al Salón de Otoño de 1929 con el mismo título ${ }^{45}$; y mejor también que el Busto de gitana con el que Ángeles Blanco concurrió al X Salón de Otoño de $1930^{46}$. Imposible, por lo tanto, que semejantes coincidencias fueran casuales; más bien me inclino por creer que las tres eligieron el mismo asunto de manera consciente y que entre ellas debía existir una buena relación que supera las cuestiones de género, pues es notorio que las exposiciones desempeñaban un papel importante tanto en la difusión de los lenguajes artísticos como en el imaginario de moda.

\footnotetext{
45 Catálogo del noveno Salón, 1929.

46 Décimo Salón de Otoño, 1930.
} 


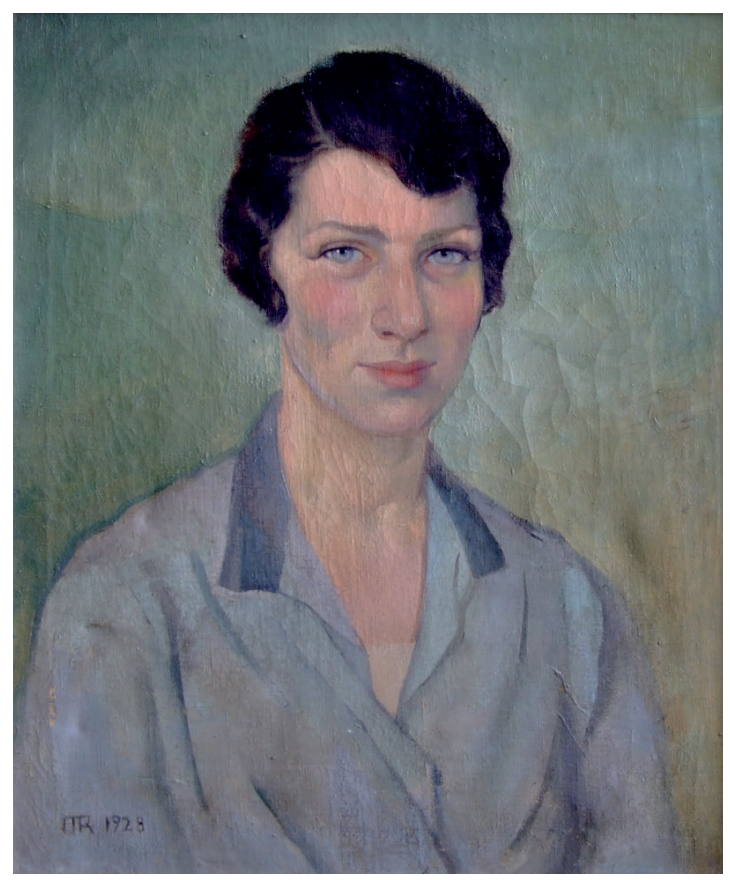

Fig. 9. Mujer en azul, 1928, Madrid, Colección C. Rodríguez

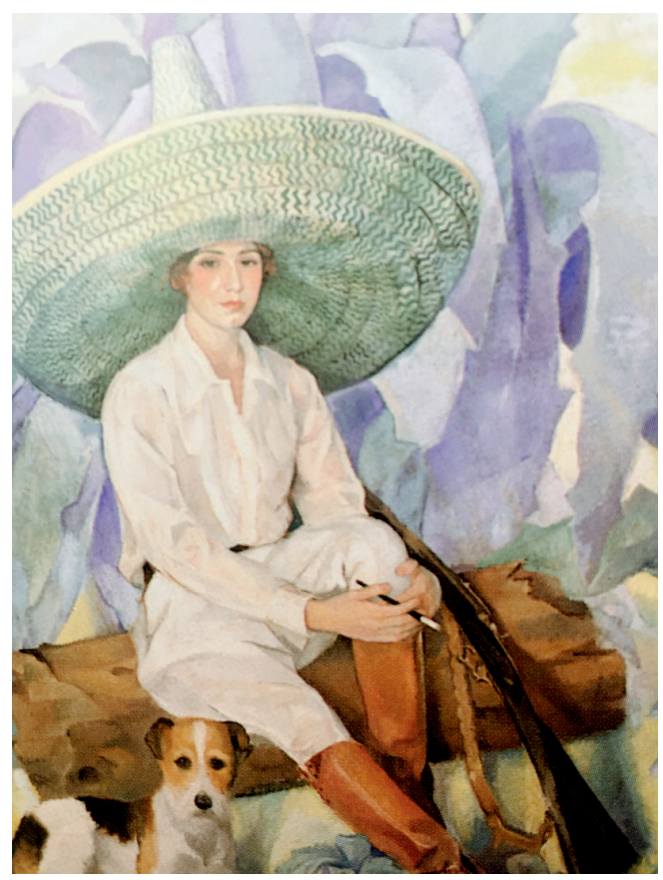

Fig. 10. Reposo, 1929, Barcelona, Museu Nacional d'Art de Catalunya

Por estas mismas fechas, Marisa Roësset introdujo una novedad entre su imaginario icónico adentrándose por derroteros poco transitados entre las creadoras españolas al pintar, de acuerdo con estos parámetros estéticos comentados, un Desnudo femenino. Sólo que su concepción - ese instante íntimo, en el que la joven muestra su cuerpo sin recato, atenta tan sólo a sus pensamientos - dista mucho de las actitudes desenfadadas y atrevidas, las miradas pícaras que todavía durante estos años lucían las fatales y perversas damas representadas ${ }^{47}$. Un asunto con el que Roësset se situaba nuevamente en la frontera, al tiempo que evidenciaba sus convicciones, y que no dudó en presentar a una de las Exposiciones Nacionales en cuyo catálogo fue reproducido. Todavía en 1932 lo conservaba en su Estudio ${ }^{48}$.

Todos estos nuevos estilemas artísticos ensayados durante los tres últimos años fueron exhibidos en la muestra que a finales de 1929 presentó, junto con su amiga Gisela Ephrussi, en el Museo de Arte Moderno. Una celebración que, como ya avanzaba, constituyó otro hito sobresaliente en la trayectoria de Roësset, expresamente reconocido por la crítica de forma unánime con palabras como las publicadas en La Gaceta Literaria:

[...] Lo que sin duda cautiva con mayor fuerza en el arte de Marisa Roésset, la gentil artista inquieta, es la inteligencia con que, en todo momento, sabe regir y dominar las inspiraciones de su instinto. Es el suyo[...] un arte consciente y civilizado, un juego en el cual jamás la artista, a impulsos de su vehemencia, pierde la supremacía de su dominio. Por eso ha podido acercarse a todos los huertos y morder todas las frutas, y se halla ahora en posesión de todos los secretos, gustadas todas las sensaciones en un minuto inicial, que tiene la fruición de las apetencias inéditas, como una mañana primaveral y propicia.

Junto a esta primordial eficacia de la inteligencia destaca [...] una gran elegancia temperamental. (De ahí todas las sutilezas de su buen gusto y la naturalidad con que se produce en ella

47 Lomba, 2016: 25-64. Lomba, 2017: 305-332.

48 En la entrevista que Roësset concedió en su Academia a finales de 1932 se citan algunos de su lienzos, entre ellos este "... bello desnudo de mujer". CIL, 1932: 6. 
la adaptación de lo extravagante.) Por propios dictados de su espiritual elegancia, el arte de la señorita Roésset resulta siempre refinado, selecto y - he aquí una noble lección- contenido, dominado, estricto.

Su talento, su elegancia, su buen gusto se unen a un sereno y claro impulso juvenil y audaz que, desde sus inicios pictóricos, la libertó para siempre del imperdonable pecado de la vulgaridad.

En las obras recientemente expuestas, y que abarcan las distintas etapas de su breve y triunfal carrera artística, se valorizan, destacándose netamente, los momentos distintos de una evolución pictórica, cuya inquietud, crismada de gracia, reflexiva, no ha sido más que una preparación. [...] $]^{49}$.

La exposición supuso también un triunfo para la pintura de género. Y así lo reconoció incluso la prensa menos moderna, representada en este ocasión por el ya citado Antonio Gil Fillol quien escribió:

[...] Dos pintoras que han expuesto sus cuadros en el Palacio de la Biblioteca. Dos pintoras que han sabido conquistar en el Arte una posición moderna venciendo incluso los escrúpulos de la disciplina. Dos pintoras de hoy. Hace muy poco la pintura femenina se caracterizaba por la timidez. Era pintura de labores de colegio de monjas y recordaba siempre la confección de ornamentos sagrados. Apenas la concebíamos fuera de los bastidores de bordar o en aquellos cuadritos de cañamazo que adornaban con su torpe dibujo geométrico las paredes de las salitas de costura. [...] Vigée-Le Brun debió parecer inaudito prodigio. Mary Cassat, a pesar de que los tiempos ya eran otros, todavía maravilló a los impresionistas [...]

Ahora ya se han borrado las fronteras del sexo. Ante los lienzos de Marisa Roésset y Gisela Ephrussi no puede hablarse de pintura femenina en el sentido en que hubiéramos hablado hace unos años $[\ldots]^{50}$.

Y como si hiciera caso a los comentarios recibidos, Roësset siguió evolucionando en esa figuración de carácter moderno que durante los años treinta caracterizó la que, a mi juicio, constituye su segunda etapa artística. La Virgen que pintó hacia 1929 y que un año después exhibió en la Exposición Nacional ${ }^{51}$, en la sala de los modernos - junto a las obras de Berdejo, Pelegrín, el propio Vázquez Díaz, Cossío, Souto...-, aunque no hubieran llevado "[...] los cuadros subversivos [...]" ${ }^{\prime 52}$, constituyó a mi entender un punto de inflexión a partir del cual desarrolló una nueva estética (fig. 11). La definición de la pintura — un Autorretrato, en mi opinión- partía del vocabulario estrenado en Italia, sólo que con un tratamiento distinto: una pintura de pinceladas más sutiles, menos tensas, inmersas en atmósferas menos construidas, más delicadas, en las que se atisbaba un cierto lirismo. Impregnada, eso sí, por una tristeza similar.

Esa fue, en líneas generales, la estética que caracterizó a la artista durante este segundo período, lejos ya de las influencias de Vázquez Díaz, cuya iconografía se nutrió, esencialmente, de figuras religiosas concebidas como sus protagonistas anteriores. En realidad, Marisa Roësset siguió pintando a sus seres más queridos, comenzando por su hermano Mauricio, al que tan pronto convirtió en ángel como en Niño Jesús o en San Juanito (fig. 12). Y con semejantes hallazgos concurrió a todas las Nacionales que se celebraron durante estos años hasta el estallido de la guerra civil, logrando la misma repercusión y similares elogios. De hecho, críticos tan célebres como Juan de la Encina, al contemplar las obras expuestas en la Nacional de 1934, alabaron su producción - junto con la de Rosario de Velasco y Julia Minguillón - con estas significativas palabras:

[...] Dan lecciones de atrevimiento a sus compañeros de Exposición. Abordan temas difíciles, caminando, como buenas y valientes amazonas, hacia una pintura de empaque clásico, que es ningún caso está reñida con la expresión de lo contemporáneo; abordan la pintura religiosa, que

49 R.M., 1930: 12.

50 Gil, 1930

${ }^{51}$ La obra debió ser considerada importante pues su fotografía fue publicada en el catálogo. Exposición Nacional, 1930:18.

52 La cita ha sido tomada de Caparrós, 2015: 543. 


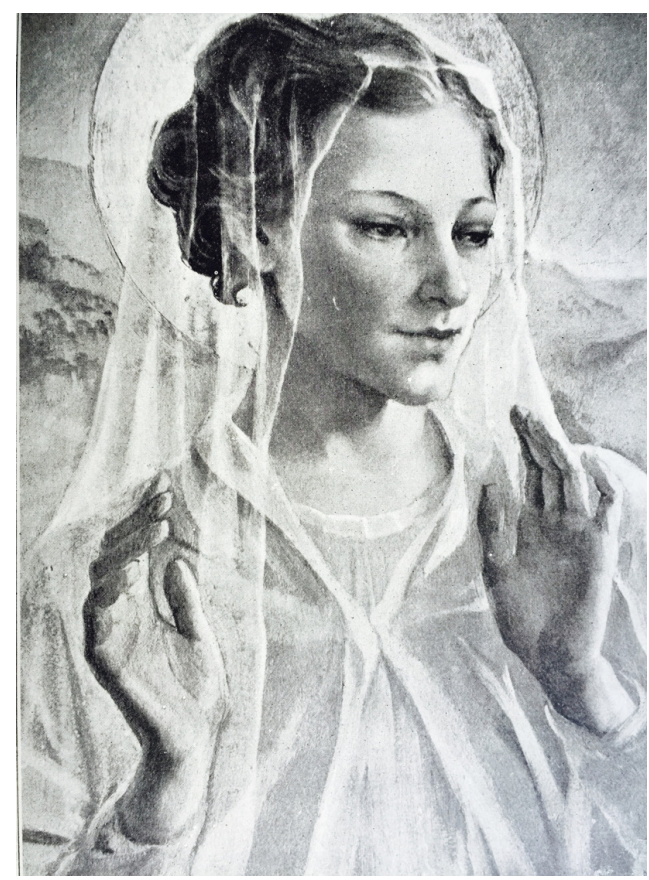

Fig. 11. La Virgen, h. 1929, Exposición Nacional de Bellas Artes. Catálogo Oficial, p. 18

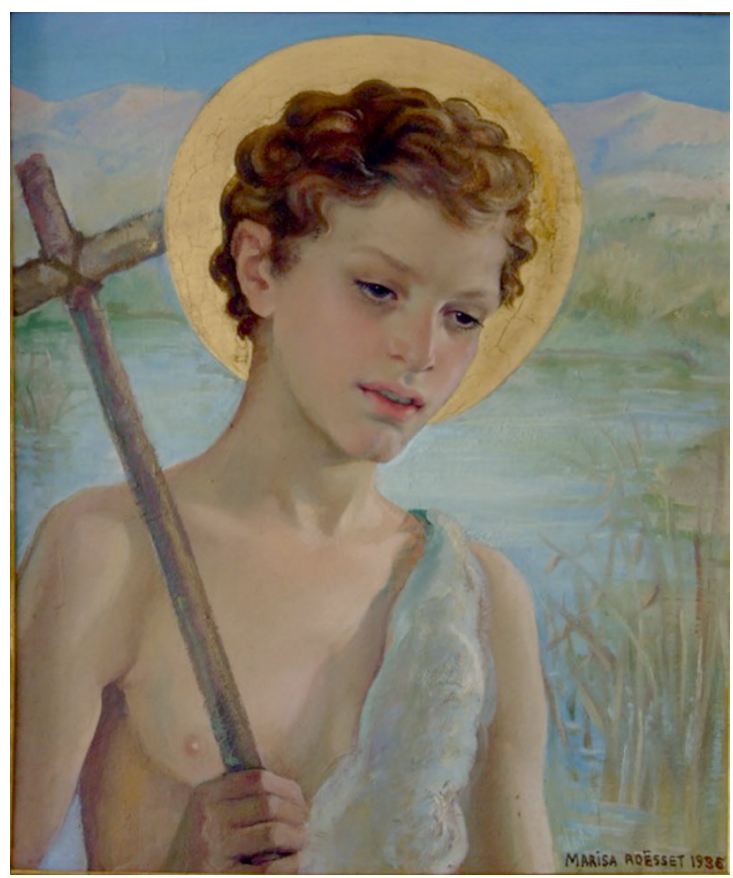

Fig. 12. San Juanito, 1936, Madrid, Colección C. Rodríguez.

parecía totalmente muerta entre nosotros, y le dan una gracia y una emoción que contrasta con esa falsa pintura piadosa, que a veces realizan por encargo y sin sentirla nuestros artistas. Estas mujeres parece que tienen conceptos más precisos y más altos de la pintura que la mayoría de nuestros artistas varones.

En fin, debemos confesarlo mal que nos pese a los que sentimos exceso de simpatía por eso que se llama feminismo; ni más ni menos que en la Universidad o en las profesiones liberales estas mujeres artistas (también... Margarita Frau) hacen su papel con discreción y talento [... $]^{53}$.

Al acabar la guerra civil, aquella moderna y decidida joven, convertida luego en amazona independiente, en maestra de artistas, que hacia 1938 emprendió una nueva aventura vital en compañía de la destacada soprano y pedagoga Lola Rodríguez Aragón (1910-1984) ${ }^{54}$, prosiguió su trayectoria. Continuó pintando y trabajando en su Escuela, lugar de referencia aunque nunca suficientemente reconocida. Sólo que su estilo había cambiado, como les ocurrió a cuantos creadores sufrieron aquella profunda brecha en sus vidas y en sus trayectorias. Más todavía a las artistas.

Durante los años cuarenta y cincuenta optó por un lenguaje más académico, menos avanzado, componiendo lienzos de gran calidad — autorretratos, imágenes religiosas... ${ }^{5}$ — y destreza téc-

53 Encina, 1934: 12; y Caparrós, 2015: 543.

${ }^{54}$ La soprano Lola Rodríguez Aragón, fundadora de la Escuela Superior de Canto de Madrid, conservó una parte importante del legado artístico de Roësset. A sus herederos, amigos y dirección de la Escuela agradezco su amabilidad, en especial a P. Pérez Iñigo, A. Higueras, C. y M. Rodríguez Aragón.

55 Entre la producción menos conocida de Roësset destacan media docena de lienzos que hemos podido contemplar a través de fotografías en papel y placas fotográficas conservadas en el Archivo Balmes. Figuran dos Retrato de amazona, fechados en 1949 y 1950; Adoración de 1950; Presentación de Jesús ante los doctores, datado en 1952; Autorretrato de amazona, pintado en 1955; Cristo en la cruz de madera, de 1956; y San José y el Niño de 1957. MNCARS, Archivo Balmes, caja 391. 
nica, hasta que en 1976 falleció. Sin embargo, la pintora moderna que irrumpió en la escena pública española al mediar los años veinte brindándonos un magnífico legado permanecerá para siempre en nuestra memoria gracias a las dotes artísticas con que los dioses la adornaron.

\section{BIBLIOGRAFÍA}

Alberti, Rafael (1994): La Arboleda perdida. En: http://www.hermanotemblon.com/biblioteca/Literatura\%20en\%20General\%20/Alberti,\%20Rafael-La\%20arboleda\%20perdida.pdf [consultado el 29-XI-2016].

Baroja y Nessi, Carmen (1998): Recuerdos de una mujer de la generación del 98. Prólogo, edición y notas de Amparo Hurtado. Barcelona: Tusquets.

Brihuega, Jaime y García, Isabel (comisarios) (2005): Daniel Vázquez Díaz 1882-1969. (Catálogo), Madrid: Museo Nacional Centro de Arte Reina Sofía, Museo de Bellas Artes de Bilbao.

Brihuega, Jaime (1995): "La ESAI y el arte español en la bisagra de 1925". En: Brihuega, Jaime Lomba, Concha (comisarios) (1995): La Sociedad de Artistas Ibéricos y el arte español de 1925. Madrid: MNCARS-Ámbit Servicios Editoriales, pp. 15-31.

C. L. (1934): "Pintura. Elogio a Marisa Roesset", Euzkadi, 4-VIII.

Caparrós Masegosa, Lola (2015): Fomento artístico y sociedad liberal. Exposiciones nacionales de Bellas Artes (19171936), Granada: Universidad de Granada: Universidad Nacional de Educación a Distancia.

Capdevilla-Argüelles, Nuria (2013): Autoras y precursoras. Un siglo de autoras Roësset. Madrid: Editorial Horas y Horas, pp. 115-139.

Catálogo del noveno Salón de Otoño fundado por la Asociación de Pintores y Escultores 1929. Madrid, octubre.

Danceny (1927): “Crónica Mundana”, La Esfera, 29-I.

Diego, Estrella de (1987): La mujer y la pintura del XIX español (Cuatrocientas olvidadas y alguna más). Madrid: Cátedra.

Décimo Salón de Otoño fundado por la Asociación de Pintores y Escultores. Catálogo de pintura, escultura, grabado, y Arte Decorativo (1930): Madrid, Octubre.

Domenech (1926): $A B C, 30-\mathrm{V}$, p. 3.

Encina, Juan de la (1934): "Las mujeres en la Exposición”. En: El Sol, 17-VI, p. 12.

Exposición Nacional de Bellas Artes. Palacios del Retiro, mayo y junio 1930. Catálogo Oficial (1930).

García de Valdeavellano, Luis (1926): "La Exposición Nacional de Bellas Artes. La pintura”. En: La Época, Madrid, 17VI, p. 1.

Gil Filoll, Antonio (1930): "Marisa Roësset y Gisela Ephrussi”. En: Estampa, 7-I.

Jardel Codina, Josefina (1936): "La mujer en el arte. Interviu breve". En: Mundo Femenino, enero-febrero, pp. 110-111.

Lago, Silvio (1924): "La Exposición Nacional". En: La Esfera, 5-VII.

Lago, Silvio (1926): "La exposición Nacional. La pintura". En: La Esfera, 14-VI.

Lomba, Concha (2014): “El umbral hacia la libertad. Artistas en España entre 1900 y 1926”. En: Illán, Magdalena / Lomba, Concha (comisarias): Pintoras en España 1859-1926. De María Luisa de la Riva a Maruja Mallo (catálogo), Zaragoza: Universidad de Zaragoza-Diputación de Zaragoza, pp. 50-69.

Lomba, Concha (2015): "Mujeres artistas. Entre la República y el exilio". En: Alba Pagan, Ester/Pérez Ochando, Luis (eds.) (2015): Mujeres que representan. Mujeres representadas. Madrid: CSIC, pp. 599-616.

Maria Roesset (1882-1921) (1988). (Catálogo), Madrid: Centro Conde Duque.

Méndez Casal, Blanco y Negro (1926): 16-V, p. 28.

Mujeres en Vanguardia. La Residencia de Señoritas en su centenario (2015): (catálogo), Madrid: Publicaciones de la Residencia de Estudiantes.

Mur, Pilar (1985): La asociación de artistas vascos, Bilbao: Museo de Bellas Artes de Bilbao-Caja de Ahorros Vizcaína.

Murga, Idoia (2015): "Muros para pintar: Las artistas y la Residencia de Señoritas", La Residencia de Señoritas en su centenario (catálogo), Madrid: Publicaciones de la Residencia de Estudiantes, pp. 102-111.

Pantorba, Bernardino de (1948): Historia y crítica de las Exposiciones Nacionales de Bellas Artes celebradas en España. Madrid: Alcor

Peláez Valle, José María (2007): "Una muestra del legado estilístico de Sotomayor en su discípula Marisa Roësset”. En: Castrelos: revista do Museo Municipal "Quiñones de León”, 13, Vigo, pp. 90-95.

R. M. (1930): “Exposición Roesset-Ephrussi”, La Gaceta Literaria, 1-I, p. 12.

Vegue y Goldoni, Ángel (1924): "La Exposición Nacional de Bellas Artes. Una ojeada a la sala decimocuarta”. En: El imparcial, 26-VI, p. 3.

Fecha de recepción: 12-I-2017

Fecha de aceptación: 25-IV-2017 